\title{
The Effect of COVID-19 on International Trade: Evidence from Sub-Saharan Africa
}

\author{
Espoir Lukau Matezo ${ }^{*}$ (1) , Boaz Mingiedi Matondo ${ }^{*}$ (1) \\ ${ }^{1}$ Hefei University of Technology, Hefei, China \\ ${ }^{2}$ Bircham International University, Kinshasa, Democratic Republic of Congo \\ Email: ^hopelukau@gmail.com, ^boazmingiedi@yahoo.fr
}

How to cite this paper: Matezo, E. L., \& Matondo, B. M. (2022). The Effect of COVID19 on International Trade: Evidence from Sub-Saharan Africa. American Journal of Industrial and Business Management, 12, 73-87. https://doi.org/10.4236/ajibm.2022.121006

Received: December 19, 2021

Accepted: January 25, 2022

Published: January 28, 2022

Copyright (c) 2022 by author(s) and Scientific Research Publishing Inc. This work is licensed under the Creative Commons Attribution International License (CC BY 4.0).

http://creativecommons.org/licenses/by/4.0/

\begin{abstract}
The purpose of this paper is to present evidence for the effect of coronavirus disease 2019 on international trade. Accordingly, we investigate trade among Sub-Saharan African countries during the first quarter of 2020. The disease problem of COVID-19 is measured based on the number of cases and deaths. The findings of this study show that the COVID-19 problem in exporting countries has a significantly negative effect on trade and positive significance in importing countries. This negative effect of exporters' COVID-19 crisis is seen in exports from developing countries. The COVID-19 problem in an exporter's neighboring nation has a positive impact on its exports. Importers' COVID-19 problem has positive effects on trade in the agricultural industry, while exporters' COVID-19 problem has adverse effects, for the most part, in the textile, footwear, and plastic industries.
\end{abstract}

\section{Keywords}

COVID-19, International Trade, Sub-Saharan Africa, Development

\section{Introduction}

The COVID-19 universal pandemic has caused many African countries suffering from starvation and disease, limited economic funding, and under-resourced health systems. Richard Marlink, director of Rutgers Global Health Institute and global response to HIV/AIDS, comprehends what it means to address health problems in Sub-Saharan African countries, home to more than 1 billion people (Watkins, 2020).

After the COVID-19 pandemic brings into being, the countries of Sub-Saharan Africa generally ill-prepared to contain the virus or deal with their economic fallout (El-Sadr \& Justman, 2020; Vidya \& Prabheesh, 2020). The healthcare system's 
capacity to prevent the spread of infection, handle emergencies, and provide care for the sick was frail due partly to too many years of underinvestment in the healthcare system. There was a deficiency of fiscal space to sufficient fund either containment or interventions in the health sector or safety nets to alleviate the effects of these interventions, particularly for low-income members of the population. For most of the poor, a mixture of low personal precautionary savings and the incapability to access the credit system in the absenteeism of a formal welfare system destined that they had no means to finance their subsistence during lockdowns. A high-pitched decline in remittances exacerbated this difficulty.

These features shaped the type and effectiveness of responses to the pandemic and their impacts on lives and livelihoods in the region (El-Sadr \& Justman, 2020).

The coronavirus roots coronavirus disease 2019 (COVID-19), as said by the World Health Organization (WHO), known as the pandemic in the last months of 2019. Referring to the WHO website, as of 16 May 2020, more than 300,000 people were lost from COVID-19 and reported worldwide. For slowing the feast of the coronavirus, many countries have imposed restrictions on people and industries. Many countries have professed citywide or national lockdowns. Similarly, many countries have set an entry ban on foreigners. Such limits have seriously harmed the world economy. For instance, China's economy shrank by $6.8 \%$ in the first quarter of 2020. This reduction is the first contraction since 1992 when China originated liberating its GDP data. Rendering to the World Economic Outlook, April 2020 by the International Monetary Fund (IMF), the international economy is sharply projected to agree by $-3 \%$ in 2020 (Velavan \& Meyer, 2020).

Rapidly, Economists have responded to this pandemic and examined the economic effects of COVID-19. An electronic book entitled Economics in the Time of COVID-19 stood on the loose by (Baldwin \& Di Mauro, 2020). It comprises simulation results, conceptual and theoretical contexts for the economic effects of COVID-19. Moreover, the Centre for Economic Policy Research threw a new online assessment review on COVID-19 studies named "COVID Economics: Vetted and Real-Time Papers". It contains formal investigations on numerous effects of COVID-19, with those on people's mobility, finance, and gender equality. Nevertheless, to our knowledge, no studies have empirically scrutinized the impact of COVID-19 on international trade, especially for Sub-Saharan Africa (Baldwin \& Di Mauro, 2020).

Based on a theoretical perspective, COVID-19 can be predictable to impact global trade in various ways substantially. Indeed, a more COVID-19 severe problem in an exporting country makes the production scale decrease, leading to a reduction in export supply. Exports will decrease, notably in industries and countries where remote work/operation is less feasible. The COVID-19 problem in importing countries is mainly due to decreased collective demand in those countries. Decreased incomes and fewer appointments to retail stores will reduce the 
need (Mboera et al., 2020). The international trade of one nation may also be affected by the COVID-19 problem in its neighboring countries. For instance, decreased exports from a pretentious country create an export opportunity for its neighbors. On the other hand, adverse production shocks due to COVID-19 in a country may reduce production in neighboring nations through supply-chain systems.

To empirically study the effects of COVID-19 on international trade, we regress bilateral trade values on various measures for assessing the problem of COVID-19. We use trade data from January up to August 2020. Trade data covering a more extended period will become available over time. Still, we decided to examine trade during this period because there had already been a severe number of COVID-19 cases and deaths, especially by the end of March 2020. Also, some nations enacted entry bans on immigrants of specific nationalities from January 2020. Our dataset includes trade among 46 Sub-Saharan African countries. Our use of worldwide data implies the solid external rationality of our results. We use the numeral of COVID-19 cases and deaths collected by the African Centre for Disease Prevention and Control as measures of disease problems to investigate the effects of COVID-19 on international trade.

\section{Influences on African Poverty and Economies}

African nations have agonized significant damage to their frugalities due to shutting down activity at home as part of a containment strategy. Perhaps the enormous damage was brought about by immediate global reaction to the pandemic, particularly the conclusion of closing of borders (impacting trade flows and tourism), the collapse of global demand (for example, for oil, affecting African oil producers), disturbance of supply chains (Melaine \& Nonvide, 2020).

In its July 2020, regional economic viewpoint for the region, the International Monetary Fund (IMF) schemes that the region's economy will therapist by 3.2 percent in 2020 before recovering to a growth of 3.4 percent in 2021. The failure in 2020 is dominated by the two largest economies in the region: Nigeria and South Africa (with contractions of 5.4 percent and 8 percent, in turn). Exclusive of these, the region's recession would be significantly shallower, at -0.6 percent, and would recover faster with a 2021 growth of 3.8 percent. Fourteen out of 45 nations will avoid a downturn but grow at significantly lesser rates compared to 2019 (Laborde, Martin, \& Vos, 2021).

The region has organized its first setback in poverty alleviation in two decades, threatening to reverse all the gains made to achieve the millennium development goals. Low-income households were more severely impacted. The International Labor Organization estimates that 85.8 percent of Africans depend on employment in the informal sector for their livelihoods daily. A policy brief available in May 2020 by the International Growth Centre estimates that an additional 9.1 percent of the population in Sub-Saharan Africa have immediately fallen into extreme poverty due to COVID-19, with 65 percent of that increase resulting 
from the lockdowns alone. It further estimates that 3.6 percent of the population in the region, including 3.9 million kids under the age of five, has fallen into severe food deprivation. Therefore, the task of recovery is not simply one of reviving growth but also of dealing with distributional consequences and pushing the group that has fallen below the poverty threshold back up (Aragie, Taffesse, \& Thurlow, 2021).

\section{The Post-COVID-19 Reactions}

The speedy response has been to prioritize the protection of the economy as a going concern during this storm to allow quick retrieval out of the crisis and avoid an extended process for normalization. Learned from the global monetary crisis and the prolonged recession that followed, it is wise to keep as many as possible in the engagements/jobs and bear the costs of maintaining open businesses rather than shed off labour and face the hurdle of rehiring later. Support for the retrieval of small and medium enterprises and informal sector undertakings are the key to the livelihoods of the widely held Africans (Edmonds, Zuckerman, \& Conant, 2021).

Moreover, the comebacks have demonstrated the role digital knowledge of technology can play in coping policies during crises. Those who can access digital connectivity managed to cope better with isolation; the use of that technology permeated the way people interacted, helping to enhance social capital, which is essential to African livelihoods. The social response to COVID-19 also demonstrated alternative ways to deliver services such as education and health. The pandemic has created the rationale for accelerating and broadening the digitalization of entire economies with presence as its central target. Digital willingness is pivotal for success, and so is the favourable policy and regulatory framework for innovation (Herold, Nowicka, Pluta-Zaremba, \& Kummer, 2021).

There is still significant doubt about the recovery path for the region due to the indecision of the way of contagion after reopening from lockdowns. The IMF approximates global growth recovery at 5.4 percent in 2020 from a deterioration of -4.9 percent in 2019, compared to Sub-Saharan Africa's recovery of 3.4 percent in 2020 from a worsening of -3.2 percent in 2019. The IMF forecasts that the region will not get back to a pre-pandemic level of GDP until 2022/23, and they are requested to work hard. In the absence of more excellent means to finance their survival, countries will have to rely more on responsible personal behaviour and voluntary social distancing, as a matter of not only safeguarding their social capital but for their self-preservation (Qian \& Zhang, 2021).

\section{Theoretical Framework}

In this part, we discourse the theoretical background of how COVID-19 touches trade between some countries. The spread of transmittable diseases in a country affects both the demand and supply sides of that country's economy. We summarize the possible effects of the COVID-19 problem in exporting and importing nations separately. We also talk about the impact of the COVID-19 crisis in 
their neighbouring countries.

\subsection{Responsibilities Related to COVID-19 in Exporting Nations}

The spread of COVID-19 has run to lockdown and social distancing measures. These policies decline people's mobility in workplaces and their economic centres. School closures force various workers to be absent from work to care for their children. Death in a straight line reduces the size of the workforce. These changes minimize supply supplies and subordinate their price elasticity, shifting the country's supply curve rising and making it sharper. In addition, it is natural that the COVID-19 problem in an exporting country results the reductions of the scale of production, which leads to a decrease in export supply (Mwananyanda et al., 2021).

However, there are two essential elements responsible for the net outcome on exports. One is decreased domestic demand for exported goods. The COVID-19 problem may shrink the production of manufactured goods and national demand for that product. If the domestic market decrease is more prominent than the fall in production, a net upsurge in exports could be understood by diverting the amount not consumed at home to the export market. In other words, the relative greatness of the scale of production over the size of domestic demand plays a crucial role in defining the net effect on exports.

The other element is the effect of presenting remote operation on productivity. Many nations have attempted to sustain economic activity by offering such telecommuting schemes. If these systems improve productivity or efficacy, exports could increase. Firstly, the production scale would decrease much more in countries or industries where remote work/operation is less feasible. For example, it isn't easy to realize such function in labour-intensive sectors or industries that need an in-person occurrence for production. Secondly, it is also less feasible in nations with less advanced information technology infrastructure. Exports are likely to reduce such industries and countries due to decreased productivity (Ntoumi \& Velavan, 2021).

\subsection{Responsibilities Related to COVID-19 in Importing Nations}

The effect of the COVID-19 problem in an importing republic on trade will mostly come from a decrease in aggregate request in that country. Citywide/nationwide lockdowns decrease people's earnings from business and lead to a drop in collective demand unless the government provides enough benefits to cover the loss of profits. Though, even if people preserve their earnings, the fear of infection decreases their visits to retail stores or supermarkets, resulting in reduced demand. As is designated by (Eaton et al., 2016), who investigated the effect of the global recession in 2008-2009 on trade, adverse demand shocks could reduce spending on durable goods more than spending on non-durable goods (Eaton, Kortum, Neiman, \& Romalis, 2016). This more significant reduction is because durable products are "postpone-able" (Baldwin \& Tomiura, 2020). On the other hand, inde- 
cision about the future or "panic buying" may increase request for non-durable products. In addition, the import request for cleanliness products, such as face masks and hand antiseptic, may increase due to increased request for products that defend against COVID-19 infection (Figure 1).

COVID-19 infections and deaths decrease or stop, and lockdown measures are raised; this swift shift from offline shopping to online shopping is expected to persevere, at least to some grade. As (Watanabe et al., 2020) recommended, buyers, need to make sincere investments to switch to online trade. After these investments are made, people become disinclined to return to the status quo, and this new style of ingesting will continue. In other words, the adverse effects are likely to continue on the imports of merchandises that are difficult to purchase online (Watanabe, Allen, Wrapp, McLellan, \& Crispin, 2020).

\subsection{Responsibilities Related to COVID-19 in Exporting Countries}

The international trade of one state may be affected by the COVID-19 problem in its neighboring countries. The commitment in neighboring countries has contrasting effects on business. One is a positive effect. Decreased exports from a country's neighbors due to COVID-19 create an export occasion for that country because importing countries may vary their import source from the neighboring countries. We may call this consequence the "substitution effect." Also, decreased imports in the neighboring countries affected by COVID-19 may lower market prices due to reduced demand levels. This falls in trade prices of the international market may rise implications in other states.

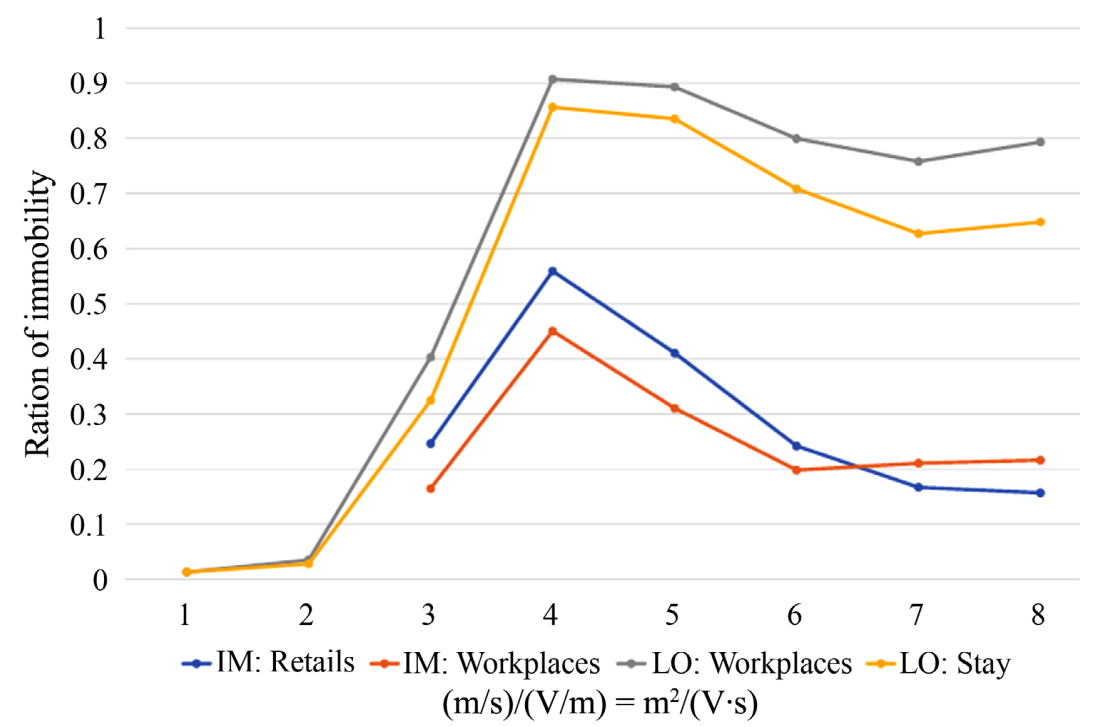

Figure 1. The world average of immobility and shares of lockdown dates by months. "IM: Retail" and "IM: Workplaces" respectively denote the global averages of stillness in relation to shops and workplaces, which is 0.15 for places of commerce and 0.21 for places of work for the last semester. "LO: Workplaces" and "LO: Stay" refer to the global average shares of dates with workplace closure and lockout orders (stay-at-home orders), respectively. Source (COVID-19 community mobility reports from Google and OxCGRT). 
The other one is called "contagion effect" it is a negative effect. Adverse production shocks resulting from COVID-19 in a country may reduce the production of other countries through supply-chain networks. For instance, International trade, and (FDI) foreign direct investment play a more significant role in conveying shocks to domestic production in other states because the elasticity of substitution between imported intermediates and domestic factors is smaller (Ghandi et al., 2019). Also, as suggested by (Halpern, Koren, \& Szeidl, 2015), decreased imported inputs results in lowering producers' productivity. Furthermore, abridged imported inputs increase the prices of products due to input-output relations. As a result, exports of a state drop if it trusts on materials or intermediates imported from neighboring countries with a COVID-19 burden (Tucker et al., 2018).

\section{Empirical Background}

This section presents our empirical outline for investigating the impacts of COVID19 on international trade. We specify the trade model as follows:

$$
\begin{aligned}
\text { Trade }_{i j t}= & E X P\left\{\alpha_{1} R T A_{i j t}+\alpha_{2} \ln G D P_{i t}+\alpha_{3} \operatorname{lnGDP} P_{j t}+\alpha_{4} C O V I D_{i t}\right. \\
& \left.+\alpha_{5} \operatorname{COVID}_{j t}+\delta_{i j}+\delta_{t}\right\} \cdot \epsilon_{i j t}
\end{aligned}
$$

Trade $_{\text {itym }}$ stands for export values from the nation $I$ to $\mathrm{j}$ at time $t$. As a timevariant nation-pair element, a Regional Trade Agreement (RTA) dummy variable is familiarized that takes a value of one if two nations are members of the same RTA and zero or else $\left(R T A_{i j t}\right)$. The time-variant exporter and importer features include the respective nation's logged GDP $\left(\operatorname{In} G D P_{i t}\right)$. Moreover, in this study, we undertake that time-variant exporter and importer features include the extent of COVID-19 liability in the respective nation $\left(C O V I D_{i t}\right)$. $\delta_{i j}$ represents nation-pair fixed effects controlling for time-invariant country-pair characteristics, such as geographical distance between the two nations. $\epsilon_{i j t}$ stands for a disturbance term. This equation was estimated by the Poisson Pseudo Maximum Likelihood (PPML) method.

Data used are from both exports and imports in reporting nations in SubSaharan Africa. The export values are encompassed in the dataset after multiplying 1.05 to adjust freight and insurance charges roughly. The data on Growth Domestic Product are taken from the World Economic Outlook by the IMF. Notice that we use the (Vidya \& Prabheesh, 2020) figure for January-March in (Vidya \& Prabheesh, 2020). We capture those impacts solely by COVID ${ }_{i t}$ Because we emphasis on trade in the first quarter of each year, we can understand our inclusion of GDP in the preceding year as controlling for the request/production conditions just before the first quarter. The RTA dummy variable is drawn from (Egger \& Larch, 2008) and its 2020 update using RTA information obtainable on the World Trade Organization website (Egger \& Larch, 2008).

As mentioned earlier, we use the number of COVID-19 cases and deaths collected by the African Centre for Disease Prevention and Control (ACDPC) as mea- 
sures of the COVID-19 burden. These data have been collected daily from health authority reports worldwide. We use the sum of cases and deaths during January-March 2020. These numbers are set to zero for January-March 2019. We add a value of one to them and then take their logs. It is also worth noting what these variables indicate. One issue is that these two numbers may have different impacts on trade because of differences in mortality among countries. Nevertheless, an increase in either number prompts governments to implement measures to protect people and companies. Thus, we interpret both numbers as indicating the degree of incentive or the probability for such actions.

Before reporting our estimation results, we give an overview of the COVID-19 burden. Table 1 lists the top 5 countries in terms of the number of deaths as of 31 March. The data are obtained from the COVID-19 Community Mobility Reports by Google and indicate the percent change in visits to retail stores and recreation sites and workplaces.

\section{Data Analysis for Empirical Results}

This section reports the estimation results. We cluster standard errors by country pairs. Columns (i) and (ii) in Table 1 show baseline results. In both columns, the dependent variable is trade values. The extent of the COVID-19 problem is

Table 1. Baseline estimation results.

\begin{tabular}{|c|c|c|c|c|c|c|}
\hline & (i) & (ii) & (iii) & (iv) & (v) & (vi) \\
\hline RTA Dummy & $\begin{array}{c}0.043 \\
{[0.039]}\end{array}$ & $\begin{array}{c}0.032 \\
{[0.040]}\end{array}$ & $\begin{array}{c}0.139^{\star} \\
{[0.084]}\end{array}$ & $\begin{array}{c}0.127 \\
{[0.082]}\end{array}$ & $\begin{array}{c}0.051 \\
{[0.040]}\end{array}$ & $\begin{array}{c}0.041 \\
{[0.039]}\end{array}$ \\
\hline Ln Importer's GDP & $\begin{array}{c}0.157 \\
{[0.165]}\end{array}$ & $\begin{array}{c}0.126 \\
{[0.158]}\end{array}$ & $\begin{array}{c}0.536^{\star} \\
{[0.214]}\end{array}$ & $\begin{array}{l}0.503^{* *} \\
{[0.209]}\end{array}$ & $\begin{array}{c}0.218^{\star} \\
{[0.132]}\end{array}$ & $\begin{array}{c}0.215 \\
{[0.144]}\end{array}$ \\
\hline Ln Exporter's GDP & $\begin{array}{c}0.211 \\
{[0.225]}\end{array}$ & $\begin{array}{c}0.227 \\
{[0.213]}\end{array}$ & $\begin{array}{c}0.453^{\star} \\
{[0.260]}\end{array}$ & $\begin{array}{c}0.461^{\star} \\
{[0.247]}\end{array}$ & $\begin{array}{l}0.434^{* *} \\
{[0.176]}\end{array}$ & $\begin{array}{c}0.598^{\star * *} \\
{[0.168]}\end{array}$ \\
\hline Ln(1 + Importer's Cases $)$ & $\begin{array}{c}0.000 \\
{[0.004]}\end{array}$ & & $\begin{array}{c}0.000 \\
{[0.005]}\end{array}$ & & $\begin{array}{c}0.002 \\
{[0.002]}\end{array}$ & \\
\hline Ln(1 + Exporter's Cases $)$ & $\begin{array}{c}-0.009^{\star *} \\
{[0.004]}\end{array}$ & & $\begin{array}{c}-0.010^{\star *} \\
{[0.005]}\end{array}$ & & $\begin{array}{c}-0.010^{\star *} \\
{[0.005]}\end{array}$ & \\
\hline Ln(1 + Importer's Deaths $)$ & & $\begin{array}{l}-0.002 \\
{[0.003]}\end{array}$ & & $\begin{array}{l}-0.003 \\
{[0.004]}\end{array}$ & & $\begin{array}{c}0.003 \\
{[0.003]}\end{array}$ \\
\hline Ln(1 + Exporter's Deaths $)$ & & $\begin{array}{c}-0.011^{\star * \star} \\
{[0.003]}\end{array}$ & & $\begin{array}{c}-0.012^{\star * \star} \\
{[0.004]}\end{array}$ & & $\begin{array}{c}-0.016^{\star * *} \\
{[0.004]}\end{array}$ \\
\hline Trade Period & Jan-Mar & Jan-Mar & March & March & Jan-Mar & Jan-Mar \\
\hline COVID Period & Jan-Mar & Jan-Mar & Jan-Mar & Jan-Mar & Jan-feb & Jan-feb \\
\hline Number of Observations & 16,756 & 16,756 & 16,182 & 16,182 & 16,756 & 16,756 \\
\hline Log Pseudo Likelihood & $-5 E+10$ & $-5 E+10$ & $-3 E+10$ & $-3 E+10$ & $-5 E+10$ & $-5 E+10$ \\
\hline
\end{tabular}

Notes. Estimation results are derived by the Poisson pseudo-maximum likelihood method. ${ }^{* * *},{ }^{* *}$, and ${ }^{*}$ indicate significance at the $1 \%, 5 \%$, and $10 \%$ levels, respectively. Standard errors stated in parentheses are gathered by country pair. In all specifications, we control for country-pair fixed effects and time fixed effects. 
measured as the log of the case numbers (i) and the log of the death numbers (ii) during the same period. Control variables such as RTA dummy and GDP variables have positive, but their coefficients are not significant. The main variables of the COVID-19 problem show significantly negative coefficients for exporters only. Both the case numbers and deaths in exporting countries negatively affect trade. However, those in importing countries do not have significant coefficients. Therefore, decreases in workforce size and efficiency in exporting countries result in a decreased transaction. Although it cannot be identified whether the influence of COVID-19 decreased demand in importing countries, at the very least, it did not lead to reduced trade.

The effects of the burden of COVID-19 on total exports and imports worldwide are perhaps of interest. By using the results in column (II), that is, those using the number of deaths as a measure of the impact of COVID-19, we compute the following:

$$
\begin{aligned}
& \left.\Delta \text { Export }_{i}=\sum_{j} \text { Trade }_{i j 2019} *\left(\exp _{4} \text { COVID }_{i t}+\hat{\alpha}_{5} \text { COVID }_{i t}\right)-1\right) \\
& \text { Import } \left._{i}=\sum_{j} \text { Trade }_{i j 2019} *\left(\exp _{4} \operatorname{COVID}_{i t}+\hat{\alpha}_{5} \text { COVID }_{i t}\right)-1\right)
\end{aligned}
$$

Equation two (2) indicates the extent to which the impacts of COVID-19 affect the total worldwide exports from country $i$ in the first quarter, compared with those exports during the same period in 2019. The case of total worldwide imports is formalized in equation three (3). We compute these measures for only reporting countries in our trade data source. We conduct robustness checks on our results regarding the study period in our dependent and independent variables. In columns (III) and (IV), we replace the dependent variable with the trade values in only March. This replacement aims to address the fact that the trade contracts fulfilled in January and February might have been made in 2019, during which time most of the countries were still unaware of the impact of COVID19.

On the other hand, in columns (V) and (VI), we replace the variables for COVID-19 with those from January to February to take into account the possibility that the effects of the COVID-19 may have a time lag. Such a time lag is likely because trade may not be realized in the same month as its contract. Due to data constraints, however, we can take only a 1-month lag into account. The results of the COVID-19 variables in both kinds of robustness checks show similar products to our baseline results; that is, only exporters' COVID-19 burden has a significantly negative effect on trade. One notable difference is that the RTA dummy and GDP variables have significant coefficients in some specifications.

In Table 2, we examine how the effects of COVID-19 differ according to country income level. Accordingly, we introduce the interaction terms between COVID19 variables. A dummy variable that taking a value of one of the exporter or importer is categorized as a high-income country according to the World Bank classification. All the coefficients for importer variables are again not significant (except for the interaction term in column (vii)). 
Table 2. Estimation results based on income-level.

\begin{tabular}{|c|c|c|c|c|c|c|}
\hline & (i) & (ii) & (iii) & (iv) & (v) & (vi) \\
\hline RTA Dummy & $\begin{array}{c}0.034 \\
{[0.039]}\end{array}$ & $\begin{array}{c}0.024 \\
{[0.040]}\end{array}$ & $\begin{array}{c}0.140^{*} \\
{[0.084]}\end{array}$ & $\begin{array}{c}0.125 \\
{[0.084]}\end{array}$ & $\begin{array}{c}0.039 \\
{[0.039]}\end{array}$ & $\begin{array}{c}0.044 \\
{[0.039]}\end{array}$ \\
\hline Ln Importer's GDP & $\begin{array}{c}0.055 \\
{[0.194]}\end{array}$ & $\begin{array}{c}0.073 \\
{[0.181]}\end{array}$ & $\begin{array}{c}0.325 \\
{[0.268]}\end{array}$ & $\begin{array}{c}0.307 \\
{[0.259]}\end{array}$ & $\begin{array}{c}0.017 \\
{[0.132]}\end{array}$ & $\begin{array}{c}0.187 \\
{[0.149]}\end{array}$ \\
\hline Ln Exporter's GDP & $\begin{array}{c}0.693^{\star * *} \\
{[0.193]}\end{array}$ & $\begin{array}{c}0.740^{\star * *} \\
{[0.186]}\end{array}$ & $\begin{array}{c}0.738^{\star * *} \\
{[0.204]}\end{array}$ & $\begin{array}{c}0.751^{\star * *} \\
{[0.202]}\end{array}$ & $\begin{array}{c}0.832^{\star * *} \\
{[0.202]}\end{array}$ & $\begin{array}{c}0.806^{\star * *} \\
{[0.185]}\end{array}$ \\
\hline Ln(1 + Importer's Cases $)$ & $\begin{array}{c}0.002 \\
{[0.003]}\end{array}$ & & $\begin{array}{c}0.004 \\
{[0.004]}\end{array}$ & & $\begin{array}{c}0.003 \\
{[0.002]}\end{array}$ & \\
\hline${ }^{\star}$ High Income Importer & $\begin{array}{c}0.003 \\
{[0.002]}\end{array}$ & & $\begin{array}{c}-0.005^{\star} \\
{[0.003]}\end{array}$ & & $\begin{array}{l}-0.001 \\
{[0.004]}\end{array}$ & \\
\hline Ln(1 + Exporter’s Cases $)$ & $\begin{array}{c}-0.017^{\star * *} \\
{[0.005]}\end{array}$ & & $\begin{array}{c}-0.014^{\star *} \\
{[0.006]}\end{array}$ & & $\begin{array}{c}-0.012^{* * *} \\
{[0.003]}\end{array}$ & \\
\hline${ }^{\star}$ High Income Exporter & $\begin{array}{c}0.009^{* * *} \\
{[0.002]}\end{array}$ & & $\begin{array}{c}0.005 \\
{[0.003]}\end{array}$ & & $\begin{array}{c}0.015^{\star * *} \\
{[0.004]}\end{array}$ & \\
\hline Ln(1 + Importer's Deaths $)$ & & $\begin{array}{c}0.000 \\
{[0.003]}\end{array}$ & & $\begin{array}{c}0.003 \\
{[0.004]}\end{array}$ & & $\begin{array}{c}0.002 \\
{[0.003]}\end{array}$ \\
\hline${ }^{\star}$ High Income Importer & & $\begin{array}{l}-0.005 \\
{[0.003]}\end{array}$ & & $\begin{array}{c}-0.008^{\star} \\
{[0.004]}\end{array}$ & & $\begin{array}{c}0.001 \\
{[0.007]}\end{array}$ \\
\hline Ln(1 + Exporter's Deaths $)$ & & $\begin{array}{c}-0.022^{* * *} \\
{[0.004]}\end{array}$ & & $\begin{array}{c}-0.017^{* * *} \\
{[0.006]}\end{array}$ & & $\begin{array}{c}-0.018^{\star * *} \\
{[0.004]}\end{array}$ \\
\hline${ }^{\star}$ High Income Exporter & & $\begin{array}{c}0.015^{\star * *} \\
{[0.004]}\end{array}$ & & $\begin{array}{c}0.008 \\
{[0.005]}\end{array}$ & & $\begin{array}{c}0.028^{\star * *} \\
{[0.008]}\end{array}$ \\
\hline Trade Period & Jan-Mar & Jan-Mar & March & March & Jan-Mar & Jan-Mar \\
\hline COVID Period & Jan-Mar & Jan-Mar & Jan-Mar & Jan-Mar & Jan-feb & Jan-feb \\
\hline Number of Observations & 16,756 & 16,756 & 16,182 & 16,182 & 16,756 & 16,756 \\
\hline Log Pseudo Likelihood & $-5 E+10$ & $-5 \mathrm{E}+10$ & $-3 E+10$ & $-3 E+10$ & $-5 \mathrm{E}+10$ & $-5 E+10$ \\
\hline
\end{tabular}

Notes. Estimation results are derived by the Poisson pseudo-maximum likelihood method. ${ }^{* * *}$, ${ }^{* *}$, and ${ }^{\star}$ indicate significance at the $1 \%, 5 \%$, and $10 \%$ levels, respectively. Standard errors stated in parentheses are clustered by country pair. In all specifications, we control for country-pair fixed effects and time fixed effects.

On the other hand, we find an interesting contrast in exported variables. Although the coefficients for exporter cases and death are again estimated to be significantly negative, their interaction terms with a high-income exporter dummy have quite positive coefficients in some specifications. Particularly in the specifications in columns (v) and (vii), the absolute magnitude is similar between the noninteracted and interacted variables. This similar magnitude implies that the COVID19 burden in exporting countries has significant adverse effects when exporters are developing countries, not developed countries. This contrast may be because remote work/operation is less feasible in developing countries due to their more deficient IT infrastructure. It may also be because developing countries have a comparative advantage in labor-intensive industries, where remote work/operations less feasible. 
Next, we examine the effect of the COVID-19 problem in countries neighboring importing and exporting nations. As discussed above, the COVID-19 problem in these countries could have a significant impact on trade. Specifically, we compute the distance-weighted sum of the COVID-19 problem as shown by the following equation. Data on Geographical distance are drawn from Centre d'Etudes Prospectives et d'Informations Internationales (CEPII).

$$
\text { Neighbor's COVID }_{i t} \equiv \sum_{j \neq i}\left(\frac{\text { COVID }_{j t}}{\text { Distance }_{i j}}\right)
$$

Here COVID ${ }_{j t}$ represents the raw number of cases and number of deaths in country $j$. We introduce logs of these sums in both importing and exporting nations separately. The estimation results are shown in Table 3. The COVID-19

Table 3. Effect of neighboring countries' cases and deaths.

\begin{tabular}{|c|c|c|c|c|c|c|}
\hline & (i) & (ii) & (iii) & (iv) & (v) & (vi) \\
\hline RTA Dummy & $\begin{array}{c}0.04 \\
{[0.041]}\end{array}$ & $\begin{array}{c}0.03 \\
{[0.041]}\end{array}$ & $\begin{array}{c}0.135 \\
{[0.085]}\end{array}$ & $\begin{array}{c}0.124 \\
{[0.083]}\end{array}$ & $\begin{array}{c}0.044 \\
{[0.040]}\end{array}$ & $\begin{array}{c}0.041 \\
{[0.039]}\end{array}$ \\
\hline Ln Importer's GDP & $\begin{array}{c}0.000 \\
{[0.140]}\end{array}$ & $\begin{array}{c}0.027 \\
{[0.140]}\end{array}$ & $\begin{array}{c}0.194 \\
{[0.190]}\end{array}$ & $\begin{array}{c}0.247 \\
{[0.196]}\end{array}$ & $\begin{array}{c}0.193 \\
{[0.130]}\end{array}$ & $\begin{array}{c}0.195 \\
{[0.138]}\end{array}$ \\
\hline Ln Exporter's GDP & $\begin{array}{c}0.228 \\
{[0.226]}\end{array}$ & $\begin{array}{c}0.287 \\
{[0.219]}\end{array}$ & $\begin{array}{c}0.221 \\
{[0.246]}\end{array}$ & $\begin{array}{c}0.300 \\
{[0.243]}\end{array}$ & $\begin{array}{c}0.541^{\star * *} \\
{[0.169]}\end{array}$ & $\begin{array}{c}0.651^{\star * *} \\
{[0.167]}\end{array}$ \\
\hline Ln(1 + Importer's Cases $)$ & $\begin{array}{c}0.000 \\
{[0.004]}\end{array}$ & & $\begin{array}{c}0.002 \\
{[0.005]}\end{array}$ & & $\begin{array}{c}0.003 \\
{[0.002]}\end{array}$ & \\
\hline $\operatorname{Ln}(1+$ Exporter's Cases $)$ & $\begin{array}{c}-0.009^{\star *} \\
{[0.004]}\end{array}$ & & $\begin{array}{l}-0.007 \\
{[0.005]}\end{array}$ & & $\begin{array}{c}-0.008^{\star * *} \\
{[0.003]}\end{array}$ & \\
\hline Ln(1 + Importer Neighbors' Cases) & $\begin{array}{c}-0.018^{\star} \\
{[0.010]}\end{array}$ & & $\begin{array}{l}-0.029 \\
{[0.014]}\end{array}$ & & $\begin{array}{c}0.014 \\
{[0.009]}\end{array}$ & \\
\hline Ln(1 + Exporter Neighbors' Cases $)$ & $\begin{array}{l}-0.006 \\
{[0.011]}\end{array}$ & & $\begin{array}{l}-0.019 \\
{[0.015]}\end{array}$ & & $\begin{array}{c}0.036^{* * *} \\
{[0.009]}\end{array}$ & \\
\hline Ln(1 + Importer's Deaths $)$ & & $\begin{array}{l}-0.002 \\
{[0.004]}\end{array}$ & & $\begin{array}{l}-0.002 \\
{[0.005]}\end{array}$ & & $\begin{array}{c}0.003 \\
{[0.003]}\end{array}$ \\
\hline Ln(1 + Exporter's Deaths $)$ & & $\begin{array}{c}-0.011^{\star * \star} \\
{[0.004]}\end{array}$ & & $\begin{array}{c}-0.010^{\star *} \\
{[0.005]}\end{array}$ & & $\begin{array}{c}-0.015^{\star * \star} \\
{[0.004]}\end{array}$ \\
\hline Ln(1 + Importer Neighbors' Deaths) & & $\begin{array}{l}-0.014 \\
{[0.010]}\end{array}$ & & $\begin{array}{l}-0.022 \\
{[0.014]}\end{array}$ & & $\begin{array}{c}0.042^{\star} \\
{[0.022]}\end{array}$ \\
\hline Ln(1 + Exporter Neighbors' Deaths) & & $\begin{array}{c}0.01 \\
{[0.011]}\end{array}$ & & $\begin{array}{c}-0.012^{* * *} \\
{[0.016]}\end{array}$ & & $\begin{array}{c}-0.066^{\star * *} \\
{[0.018]}\end{array}$ \\
\hline Trade Period & Jan-Mar & Jan-Mar & March & March & Jan-Mar & Jan-Mar \\
\hline COVID Period & Jan-Mar & Jan-Mar & Jan-Mar & Jan-Mar & Jan-feb & Jan-feb \\
\hline Number of Observations & 16,756 & 16,756 & 16,182 & 16,182 & 16,756 & 16,756 \\
\hline Log Pseudo Likelihood & $-5 E+10$ & $-5 E+10$ & $-3 E+10$ & $-3 E+10$ & $-5 E+10$ & $-5 E+10$ \\
\hline
\end{tabular}

Notes. Estimation results are derived by the Poisson pseudo-maximum likelihood method. ${ }^{\star * *}$, ${ }^{\star *}$, and ${ }^{\star}$ indicate significance at the $1 \%, 5 \%$, and $10 \%$ levels, respectively. Standard errors stated in parentheses are gathered by country pair. In all specifications, we control for country-pair fixed effects and time fixed effects. 
variables in exporting countries themselves again have significantly negative coefficients. The neighbor's COVID-19 variables also have significant products, especially exporters.

Moreover, their coefficients are estimated to be significantly positive. These results are unchanged even when excluding COVID-19 variables in both importing and exporting countries themselves. These positive results may indicate the dominant role of a substitution effect between nations' economies.

Finally, we estimate our model by industry. Specifically, we regress the model specified in columns (I) and (II) in Table 1. The sector is defined by the tariff section of the harmonized system. Only the results for the COVID-19 variables are shown in Table 4. Although total trade was analyzed, we did not find significant products for importers'COVID-19 burden; however, we can see effective results in some industries. In particular, importers' COVID-19 responsibility positively affected trade in the agricultural, mineral, and leather industries. Among

Table 4. Estimation results by tariff section.

\begin{tabular}{|c|c|c|c|c|c|c|c|c|}
\hline & \multicolumn{2}{|c|}{ Importer's cases } & \multicolumn{2}{|c|}{ Exporters's cases } & \multicolumn{2}{|c|}{ Importer's deaths } & \multicolumn{2}{|c|}{ Exporters's deaths } \\
\hline & Coef & SE & Coef & SE & Coef & SE & Coef & SE \\
\hline Live animals & $0.017^{\star \star \star}$ & {$[0.006]$} & $0.032^{\star \star \star *}$ & {$[0.008]$} & 0.01 & {$[0.007]$} & $0.030^{* * *}$ & [0.007] \\
\hline Vegetable products & 0.004 & {$[0.010]$} & 0.003 & {$[0.014]$} & 0.005 & {$[0.011]$} & 0.003 & [0.008] \\
\hline Animal/ vegetable fats & -0.003 & {$[0.007]$} & -0.002 & {$[0.008]$} & -0.009 & {$[0.008]$} & -0.015 & {$[0.011]$} \\
\hline Food products & 0.006 & {$[0.006]$} & 0.005 & {$[0.006]$} & 0.000 & {$[0.006]$} & -0.001 & {$[0.005]$} \\
\hline Chemical products & $0.0014^{* *}$ & {$[0.002]$} & $0.0011^{*}$ & {$[0.010]$} & $0.0010^{*}$ & {$[0.003]$} & -0.001 & {$[0.002]$} \\
\hline Mineral products & 0.001 & {$[0.004]$} & 0.001 & {$[0.003]$} & -0.002 & {$[0.004]$} & $-0.013^{\star *}$ & {$[0.003]$} \\
\hline Leather products & -0.003 & {$[0.007]$} & -0.004 & {$[0.007]$} & -0.002 & {$[0.006]$} & -0.003 & [0.007] \\
\hline Plastics and rubber & $0.011^{*}$ & {$[0.007]$} & $0.0014^{* *}$ & {$[0.006]$} & $0.011^{\star}$ & {$[0.007]$} & 0.006 & [0.007] \\
\hline Wood products & 0.004 & {$[0.003]$} & 0.005 & {$[0.003]$} & 0.006 & {$[0.004]$} & 0.004 & {$[0.004]$} \\
\hline Paper products & -0.007 & {$[0.005]$} & -0.003 & {$[0.003]$} & -0.002 & {$[0.005]$} & $-0.018^{* * *}$ & {$[0.005]$} \\
\hline Textiles & 0.000 & {$[0.005]$} & 0.008 & {$[0.005]$} & 0.000 & {$[0.004]$} & 0.001 & [0.006] \\
\hline Plastic/glass products & 0.002 & {$[0.006]$} & 0.004 & {$[0.006]$} & 0.002 & {$[0.006]$} & $-0.009^{* * *}$ & [0.009] \\
\hline Foot wear & 0.005 & {$[0.010]$} & 0.006 & {$[0.004]$} & 0.007 & {$[0.009]$} & 0.005 & {$[0.011]$} \\
\hline Precious metals & $-0.005^{\star}$ & {$[0.006]$} & $-0.0014^{\star \star \star}$ & {$[0.006]$} & $-0.005^{\star}$ & {$[0.005]$} & $-0.015^{\star \star \star}$ & {$[0.004]$} \\
\hline Machinery & -0.006 & {$[0.004]$} & -0.005 & {$[0.004]$} & -0.005 & {$[0.004]$} & -0.006 & {$[0.003]$} \\
\hline Transport equipment & 0.000 & {$[0.006]$} & $0.006^{\star *}$ & {$[0.003]$} & 0.004 & {$[0.004]$} & $0.010^{* *}$ & [0.004] \\
\hline Miscellaneous & $0.017^{\star *}$ & {$[0.007]$} & -0.014 & {$[0.010]$} & $0018^{\star *}$ & {$[0.009]$} & -0.01 & [0.008] \\
\hline
\end{tabular}

Notes: Estimation results are derived by the Poisson pseudo-maximum likelihood method. For each section, we estimate equations specified in columns (I) and (II) in Table 2 and then report only the results for cases and deaths. ${ }^{* *},{ }^{* *}$, and ${ }^{*}$ indicate significance at the $1 \%, 5 \%$, and $10 \%$ levels, respectively. "SE" designates standard errors clustered by country pair. In all specifications, we control for country-pair fixed effects and time fixed effects. 
them, agricultural goods are considered essential for life, so uncertainty about the future might induce consumers to purchase them and increase import demand. Adverse effects of importers' COVID-19 burden can be found in the paper and machinery industries. A possible reason is that these products are postpone-able or durable products. Consumers possibly hesitate to buy these products. Also, supply-side shocks in importing countries possibly decrease demand for intermediate inputs in machinery industries through input-output linkages. On the other hand, the adverse effects of exporters' COVID-19 burden are particularly evident in textiles, footwear, and plastic/glass products. This result might be due to how these products are labour-intensive or require an in-person presence for production.

\section{Conclusion}

Based on data in the first quarter of 2020, this paper provides early evidence for the impacts of COVID-19 on worldwide trade. The spread of the COVID-19 affects both exporting and importing countries, but our findings indicate that adverse effects on business mainly come from exporters' COVID-19 burden in developing countries. The adverse effects are particularly prevalent in the textile, footwear, and plastic industries. We have also observed that the COVID-19 burden in exporters' neighboring countries positively affects exports, indicating a substitution effect in exporting. However, we found a positive impact of importers' COVID-19 responsibility on trade in the agricultural industry. This demonstrates that importers' COVID-19 burden promotes exports of essential goods to affected countries. The spread of COVID-19 causes both supply and demand shocks, but our results suggest that addressing supply-side shocks is more critical to maintaining the stability of worldwide trade. Supporting developing countries is particularly important because the COVID-19 burden results in more significant decreases in exports from these countries than those from developed countries. Facilitating work in the agricultural and food industries is also essential to meet increased demand in affected countries. We believe this paper contributes to a better understanding of the impacts of COVID-19 on the world economy and helps in considering policy responses to mitigate them.

The study presents some limitations mainly focusing on the effect of COVID-19 on international trade for a database of the first quarter of 2020, future research could focus on the impact of aid for trade in African economies, which facing debt issues and the COVID-19 crisis.

\section{Conflicts of Interest}

The authors declared no potential conflicts of interest with respect to the research, authorship, and/or publication of this article.

\section{References}

Aragie, E., Taffesse, A. S., \& Thurlow, J. (2021). The Short-Term Economywide Impacts of COVID-19 in Africa: Insights from Ethiopia. African Development Review, 33, 
S152-S164. https://doi.org/10.1111/1467-8268.12519

Baldwin, R., \& Di Mauro, B. W. (2020). Economics in the Time of COVID-19: A New eBook. VOX CEPR Policy Portal.

Baldwin, R., \& Tomiura, E. (2020). Thinking ahead about the Trade Impact of COVID-19. In Economics in the Time of COVID-19 (pp. 59-71). CEPR Press.

Eaton, J., Kortum, S., Neiman, B., \& Romalis, J. (2016). Trade and the Global Recession. American Economic Review, 106, 3401-3438. https://doi.org/10.1257/aer.20101557

Edmonds, C. E., Zuckerman, S. P., \& Conant, E. F. (2021). Management of Unilateral Axillary Lymphadenopathy Detected on Breast MRI in the Era of Coronavirus Disease (COVID-19) Vaccination. American Journal of Roentgenology, 217, 831-834. https://doi.org/10.2214/AJR.21.25604

Egger, P., \& Larch, M. (2008). Interdependent Preferential Trade Agreement Memberships: An Empirical Analysis. Journal of International Economics, 76, 384-399. https://doi.org/10.1016/j.jinteco.2008.08.003

El-Sadr, W. M., \& Justman, J. (2020). Africa in the Path of Covid-19. New England Journal of Medicine, 383, e11. https://doi.org/10.1056/NEJMp2008193

Ghandi, M., Huang, F. W., Jané-Valbuena, J., Kryukov, G. V., Lo, C. C., McDonald, E. R. et al. (2019). Next-Generation Characterization of the Cancer Cell Line Encyclopedia. Nature, 569, 503-508. https://doi.org/10.1038/s41586-019-1186-3

Halpern, L., Koren, M., \& Szeidl, A. (2015). Imported Inputs and Productivity. American Economic Review, 105, 3660-3703. https://doi.org/10.1257/aer.20150443

Herold, D. M., Nowicka, K., Pluta-Zaremba, A., \& Kummer, S. (2021). COVID-19 and the Pursuit of Supply Chain Resilience: Reactions and "Lessons Learned" from Logistics Service Providers (LSPs). Supply Chain Management: An International Journal, 26, 702-714. https://doi.org/10.1108/SCM-09-2020-0439

Laborde, D., Martin, W., \& Vos, R. (2021). Impacts of COVID-19 on Global Poverty, Food Security, and Diets: Insights from Global Model Scenario Analysis. Agricultural Economics, 52, 375-390. https://doi.org/10.1111/agec.12624

Mboera, L. E., Akipede, G. O., Banerjee, A., Cuevas, L. E., Czypionka, T., Khan, M. et al. (2020). Mitigating Lockdown Challenges in Response to COVID-19 in Sub-Saharan Africa. International Journal of Infectious Diseases, 96, 308-310.

Melaine, G., \& Nonvide, A. (2020). Short-Term Impact of COVID-19 on Poverty in Africa. Covid Economics, 15, 184-195.

Mwananyanda, L., Gill, C. J., MacLeod, W., Kwenda, G., Pieciak, R., Mupila, Z. et al. (2021). Covid-19 Deaths in Africa: Prospective Systematic Postmortem Surveillance Study. British Medical Journal, 372, n334. https://doi.org/10.1136/bmj.n334

Ntoumi, F., \& Velavan, T. P. (2021). COVID-19 in Africa: between Hope and Reality. The Lancet Infectious Diseases, 21, 315. https://doi.org/10.1016/S1473-3099(20)30465-5

Qian, F., \& Zhang, A. (2021). The Value of Federated Learning during and Post-COVID19. International Journal for Quality in Health Care, 33, Article ID: mzab010. https://doi.org/10.1093/intqhc/mzab010

Tucker, M. A., Böhning-Gaese, K., Fagan, W. F., Fryxell, J. M., Van Moorter, B., Alberts, S. C. et al. (2018). Moving in the Anthropocene: Global Reductions in Terrestrial Mammalian Movements. Science, 359, 466-469.

Velavan, T. P., \& Meyer, C. G. (2020). The COVID-19 Epidemic. Tropical Medicine \& International Health, 25, 278-280. https://doi.org/10.1111/tmi.13383

Vidya, C. T., \& Prabheesh, K. P. (2020). Implications of COVID-19 Pandemic on the Global Trade Networks. Emerging Markets Finance and Trade, 56, 2408-2421. https://doi.org/10.1080/1540496X.2020.1785426 
Watanabe, Y., Allen, J. D., Wrapp, D., McLellan, J. S., \& Crispin, M. (2020). Site-Specific Glycan Analysis of the SARS-CoV-2 Spike. Science, 369, 330-333.

https://doi.org/10.1126/science.abb9983

Watkins, J. (2020). Preventing a COVID-19 Pandemic. British Medical Journal, 368, m810.

https://doi.org/10.1136/bmj.m810 